\title{
Specificity of $S^{\prime}{ }_{1}$ and $S^{\prime}{ }_{2}$ subsites of human tissue kallikrein using the reactive-centre loop of kallistatin: the importance of $P^{\prime}{ }_{1}$ and $P^{\prime}{ }_{2}$ positions in design of inhibitors
}

\author{
Daniel C. PIMENTA, Sandro E. FOGAÇA, Robson L. MELO, Luiz JULIANO and Maria A. JULIANO1 \\ Department of Biophysics, Escola Paulista de Medicina, Universidade Federal de São Paulo, Rua Três de Maio, 100, São Paulo 04044-020, Brazil
}

\begin{abstract}
We have demonstrated that the $S_{1}^{\prime}$ and $S_{2}^{\prime}$ subsites of human tissue kallikrein (hK1) play determinant roles in the recognition and hydrolysis of substrates. The presence of serine at position $\mathrm{P}_{1}^{\prime}$ and arginine at $\mathrm{P}_{2}^{\prime}$ resulted in the best substrate, Abz-Ala-Ile-Lys-Phe-Phe-Ser-Arg-Gln-EDDnp, which was derived from the kallistatin reactive-centre loop sequence and quencher groups $O$-aminobenzoic acid (Abz) and $N$-(2,4-dinitrophenyl)ethylenediamine (EDDnp). Serine and arginine are also the residues at positions $\mathrm{P}_{1}^{\prime}$ and $\mathrm{P}_{2}^{\prime}$ in human kininogen, from which hK1 releases Lys-bradykinin. Several peptide analogues of Abz-Ala-Ile-Lys-Phe-Phe-Ser-ArgGln-EDDnp, in which the Ser and Arg residues were substituted with various other amino acids, were synthesized and tested as substrates. Most of them were hydrolysed slowly, although they showed significant binding to $\mathrm{hK} 1$, as demonstrated by their competitive inhibition constants $\left(K_{\mathrm{i}}\right)$. Using this information, six peptides were designed, synthesized and assayed as inhibitors of
\end{abstract}

hK1. Abz-Lys-Phe-Phe-Pro-Arg-Gln-EDDnp, Abz-Lys-Phe-ArgPro-Arg-Gln-EDDnp and acetyl-Lys-Phe-Phe-Pro-Leu-Glu-NH ${ }_{2}$ inhibited hK1 in the range 20-30 nM (letters in italics denote the D-form of the amino acid). The peptide acetyl-Lys-Phe-Phe-ProLeu-Glu- $\mathrm{NH}_{2}$ was a weak inhibitor for other serine proteases, as indicated by the higher $K_{\mathrm{i}}$ values compared with hK1, but this peptide was a potent inhibitor of human plasma kallikrein, which has a $K_{\mathrm{i}}$ value of $8 \mathrm{nM}$. This result was surprising, since this enzyme is known to be a restricted arginyl-hydrolase. In conclusion, acetyl-Lys-Phe-Phe-Pro-Leu-Glu- $\mathrm{NH}_{2}$ can be used as a leader compound to design specific inhibitors for hK1, plasma kallikrein, or for both at same time, if the inhibition of kinin release is the main goal.

Key words: bradykinin, inflammation, kallidin, kininogen, serine protease.

\section{INTRODUCTION}

Human tissue kallikrein (hK1) (EC 3.4.21.35) is a member of a family of three closely related serine proteases $[1,2]$, which includes two enzymes expressed in prostate, namely prostatespecific antigen (PSA; also called hK3) and a trypsin-like enzyme, hK2. This classical view has been altered by the inclusion of 14 genes in the human kallikrein gene family, some of which have been correlated with carcinogenesis [3]. hK1 is the only tissue kallikrein with established functions, which include release of Lys-bradykinin (kallidin) in inflammatory processes, such as arthritis, asthma and rhinitis [4-6], and the processing of hormone and other peptide precursors $[1,2]$. $\mathrm{hK} 1$, and the cognate enzymes in mammals, release the vasoactive decapeptide Lys-bradykinin (Lys-BK) by cleavage at $\mathrm{Met}^{379}-\mathrm{Lys}^{380}$ and $\mathrm{Arg}^{389}-\mathrm{Ser}^{390}$ in limited proteolysis from high- and low-molecular-mass kininogens [7]. The only exceptions known so far are rat tissue kallikrein (rK1), which cleaves a Lys-Arg bond and releases bradykinin from bovine and rat kininogens [8,9], and mouse submandibular tissue kallikrein [10], which also releases bradykinin. The efficiency of cleavage at the Met-Lys bond by hK1 is dependent on the extension of the substrates, as demonstrated by internally quenched fluorescent peptides with the sequence of human kininogen $[11,12]$. hK1 can also hydrolyse substrates that contain a pair of phenylalanines, for example in the reactive-site loop of $\mathrm{hK} 1-$ binding protein, a specific serpin for tissue kallikrein called kallistatin [13,14], as well as in somatostatin [15]. Although hK1 possesses homology with trypsin, the crystal structures of human and porcine tissue kallikrein $[16,17]$ show that their $S_{1}$ (see Schechter and Berger nomenclature [18]) sites are enlarged, mainly owing to the insertion of an additional residue, Pro $^{219}$, which is in the cis configuration. This unique feature of tissue kallikrein allows its $S_{1}$ subsite to accept Arg, as well as a larger and hydrophobic side chain, such as that of Phe.

In the present paper, we examined the $S^{\prime}{ }_{1}$ and $S_{2}^{\prime}$ subsite specificity of $\mathrm{hK} 1$, using the internally quenched fluorescent peptide Abz-Ala-Ile-Lys-Phe-Phe-Ser-Arg-Gln-EDDnp as a reference [where Abz is $O$-aminobenzoic acid and EDDnp is $N$ (2,4-dinitrophenyl)ethylenediamine]; this peptide is a segment of the reactive-centre loop sequence of kallistatin that has been used previously for evaluation of hK1 specificity at non-prime subsites [19]. Abz and EDDnp are the fluorescent donor and acceptor groups respectively, and glutamine was introduced as a necessary result of the solid-phase peptide synthesis strategy employed [20].

\section{MATERIAL AND METHODS}

\section{Reagents}

Homogeneous preparations of $\mathrm{hK} 1$, obtained as described previously [21], were kindly provided by Dr J. Chao of the Medical University of South Carolina, Charleston, SC, U.S.A.

Abbreviations used: hK1, human tissue kallikrein; Abz, o-aminobenzoic acid; EDDnp, N-(2,4-dinitrophenyl)ethylenediamine; MALDI-TOF MS, matrixassisted laser-desorption ionization-time-of-flight MS; PTI, pancreatic trypsin inhibitor; TFA, trifluoroacetic acid; $\lambda_{\text {em }}$, emission wavelength; $\lambda_{\text {ex }}$, excitation wavelength.

1 To whom correspondence should be addressed (e-mail juliano.biof@epm.br). 
The molar concentrations of enzyme solutions were determined by active-site titration with 4-nitrophenyl-4-guanidinobenzoate [22].

\section{Peptide synthesis}

All the intramolecularly quenched fluorogenic peptides were obtained by a solid-phase peptide synthesis strategy, the details of which are provided elsewhere [20]. An automated bench-top simultaneous multiple solid-phase peptide synthesizer (PSSM 8 system, Shimadzu, Tokyo, Japan) was used for the solid-phase synthesis of all the peptides by the fluoren-9-ylmethoxycarbonyl (Fmoc) procedure. The final deprotected peptides were purified by semi-preparative HPLC using an Econosil C-18 column $(10 \mu \mathrm{m}, 22.5 \mathrm{~mm} \times 250 \mathrm{~mm})$ and a two-solvent system: buffer A, trifluoroacetic acid (TFA)/ $\mathrm{H}_{2} \mathrm{O}(1: 1000, \mathrm{v} / \mathrm{v})$ and buffer $\mathrm{B}$, TFA/acetonitrile/ $\mathrm{H}_{2} \mathrm{O}$ (1:900:100, by vol.). The column was eluted at a flow rate of $5 \mathrm{ml} / \mathrm{min}$ with a $10-50 \%$ (or 30-60\%) gradient of solvent B over 30 or $45 \mathrm{~min}$. Analytical HPLC was performed using a binary HPLC system (Shimadzu) with a SPD-10AV Shimadzu UV-Vis detector and a Shimadzu RF-535 fluorescence detector, coupled to an Ultrasphere C-18 column $(5 \mu \mathrm{m}, 4.6 \mathrm{~mm} \times 150 \mathrm{~mm})$ which was eluted with solvent systems $\mathrm{A}$ and $\mathrm{B}$ at a flow rate of $1 \mathrm{ml} / \mathrm{min}$ and a $10-80 \%$ gradient of B over $20 \mathrm{~min}$. The HPLC column eluates were monitored by their absorbance at $220 \mathrm{~nm}$ and by fluorescence emission at $420 \mathrm{~nm}$ following excitation at $320 \mathrm{~nm}$. The molecular mass and purity of synthesized peptides were checked by matrix-assisted laser-desorption ionization-time-of-flight (MALDI-TOF) MS (TofSpec-E; Micromass, Manchester, U.K.) and/or peptide sequencing using a protein sequencer PPSQ-23 (Shimadzu).

\section{Kinetic assays}

Hydrolysis of the fluorogenic peptidyl substrates was performed in $20 \mathrm{mM}$ Tris/ $\mathrm{HCl}$ and $1 \mathrm{mM} \mathrm{EDTA}, \mathrm{pH} 9$, at $37{ }^{\circ} \mathrm{C}$ and followed by measuring the fluorescence at an emission wavelength $\left(\lambda_{\mathrm{em}}\right)$ of $420 \mathrm{~nm}$ and an excitation wavelength $\left(\lambda_{\text {ex }}\right)$ of $320 \mathrm{~nm}$ in a Hitachi F-2000 spectrofluorimeter. The $1 \mathrm{~cm}$ path length cuvette, containing $2 \mathrm{ml}$ of the substrate solution, was placed in a thermostatically controlled cell compartment for $5 \mathrm{~min}$ before the enzyme solution was added and the increase in fluorescence with time was continuously recorded for $10 \mathrm{~min}$. The slope was converted into mol of hydrolysed substrate/min, based on the fluorescence curves of standard peptide solutions before and after total enzymic hydrolysis. The concentration of the peptide solutions was determined by colourimetric determination of the 2,4-dinitrophenyl group $\left(17300 \mathrm{M}^{-1} \cdot \mathrm{cm}^{-1}\right.$ molar absorption at $365 \mathrm{~nm}$ ). The enzyme concentration for initial rate determination was chosen at a level intended to hydrolyse less than $5 \%$ of the substrate present. The kinetic parameters were calculated according to Wilkinson [23], as well as by using Eadie-Hofstee plots. All the obtained data were fitted to nonlinear least square equations using Grafit v 3.0 from Erithacus Software.

\section{Inhibition assay}

The hydrolysis of the fluorogenic peptide substrate Pro-Phe-Phe7 -methyl coumarine amide $\left(K_{\mathrm{m}}=70 \mu \mathrm{M}, k_{\text {cat }}=12.5 \mathrm{~s}^{-1}[15]\right.$; where italics denote the D-form of the amino acid) was followed by measuring the fluorescence at $\lambda_{\mathrm{em}}=480 \mathrm{~nm}$ and $\lambda_{\mathrm{ex}}=$ $360 \mathrm{~nm}$ in a Hitachi F-2000 spectrofluorimeter, at $37^{\circ} \mathrm{C}$ in $20 \mathrm{mM}$ Tris/ $\mathrm{HCl}$, pH 9.0, containing $1 \mathrm{mM}$ EDTA buffer. A $1 \mathrm{~cm}$ path length cuvette containing $2 \mathrm{ml}$ of $30 \mu \mathrm{M}$ substrate solution was placed in the thermostatted cell compartment for $5 \mathrm{~min}$ before the enzyme solution was added to $0.5 \mathrm{nM}$ final concentration, and the increase in fluorescence with time (velocity) was continuously recorded for up to $5 \mathrm{~min}$. Small aliquots of a highly concentrated inhibitor solution were added with minimal solution, and the decreased velocity was read for up to $5 \mathrm{~min}$ to ensure that no more than $5 \%$ of the initial substrate concentration was hydrolysed by the end of the assay. The $K_{\mathrm{i}}$ values for competitive inhibition assays of the peptides were determined according to Nicklin and Barrett [24].

\section{Determination of cleaved bonds}

The cleaved bonds were identified by isolation of the fragments by HPLC and the retention times of the fluorescent Abz-containing fragments were compared with authentic synthetic sequences and/or by molecular mass, which was determined by MALDITOF MS (TofSpec-E; Micromass).

\section{RESULTS}

\section{$\mathbf{P}_{1}{ }_{1}$ position}

The kinetic parameters for hydrolysis of the peptides derived from the internally quenched fluorescent peptide Abz-Ala-IleLys-Phe-Phe-Ser-Arg-Gln-EDDnp with modifications at the $\mathrm{P}_{1}{ }_{1}$ position are presented in Table 1 . We have previously reported good substrates for hK1 with synthesized peptides derived from this reference peptide [19], but with modifications at positions $\mathrm{P}_{4}-\mathrm{P}_{1}$. Most of the peptides from the family presented here, modified at the $\mathrm{P}_{1}^{\prime}$ position, were poorly hydrolysed. In fact, only substrates having Gln, Ser, Thr and Ile (peptides VI, VIII, IX and $\mathrm{X}$ respectively) were hydrolysed to an extent that allowed

Table 1 Kinetic parameters and inhibiton constant $\left(K_{\mathrm{i}}\right)$ for the simple linear competitive inhibition of hK1 for the internally quenched fluorescent peptides derived from the reactive centre loop of kallistatin, with modifications at the $\mathbf{P}_{1}$ position

Conditions: $20 \mathrm{mM}$ Tris-HCl and $1 \mathrm{mM} \mathrm{EDTA}$, pH 9, at $37^{\circ} \mathrm{C}$. *Poorly hydrolysed means that at least $70 \%$ of the initial peptide concentration $(10 \mu \mathrm{M})$ remained intact after a 4-h incubation period with $1 \mathrm{nM}$ hK1 (the usual kinetic assay enzyme concentration). The cleavage point was determined after an overnight incubation. $\uparrow A$ resistant peptide was one that, for the former conditions, presented a hydrolysis rate less than $10 \% . \ddagger K_{i}$ determined in $20 \mathrm{mM}$ Tris/ $\mathrm{HCl}$ and $1 \mathrm{mM}$ EDTA, pH 9, at $37^{\circ} \mathrm{C}$ over the hydrolysis of $20 \mu \mathrm{M}$ Pro-Phe-Phe-methyl coumarine amide $\left(K_{\mathrm{m}}=70 \mu \mathrm{M}, K_{\text {cat }}=12.5 \mathrm{~s}^{-1}[15]\right)$, employing $1 \mathrm{nM} \mathrm{hK1}$. Cleavage sites are indicated with an arrow $(\downarrow)$.One-letter symbols have been used to represent amino acids and letters in bold denote the mutated residue.

\begin{tabular}{|c|c|c|c|c|c|}
\hline No. & $\begin{array}{l}\text { Abz-peptidyl- } \\
\text { Glu-EDDnp }\end{array}$ & $\begin{array}{l}K_{\mathrm{m}} \\
(\mu \mathrm{M})\end{array}$ & $\begin{array}{l}k_{\text {cat }} \\
\left(\mathrm{s}^{-1}\right)\end{array}$ & $\begin{array}{l}k_{\text {cat }} / K_{\mathrm{m}} \\
(\mathrm{mM} \cdot \mathrm{s})^{-1}\end{array}$ & $\begin{array}{c}K_{i} \ddagger \\
(\mu \mathrm{M})\end{array}$ \\
\hline । & $A \mid K F F \downarrow A R$ & Poorly hydrolysed* & & & $0.33 \pm 0.02$ \\
\hline$\|$ & AlKFF $\downarrow$ ER & Poorly hydrolysed* & & & $0.40 \pm 0.03$ \\
\hline III & AlKFF $\downarrow$ LR & Poorly hydrolysed* & & & $0.32 \pm 0.01$ \\
\hline IV & AlKFF $\downarrow N R$ & Poorly hydrolysed* & & & $0.35 \pm 0.05$ \\
\hline V & AlKFFPR & Resistant† & & & $0.090 \pm 0.005$ \\
\hline VI & AlKFF $\downarrow \mathbf{Q R}$ & $0.13 \pm 0.01$ & $0.02 \pm 0.01$ & 154 & - \\
\hline VII & AlKFF $\downarrow \mathbf{R R}$ & Poorly hydrolysed* & & & $0.21 \pm 0.03$ \\
\hline VIII & AlKFF $\downarrow \mathbf{S R}$ & $0.36 \pm 0.01$ & $3.33 \pm 0.15$ & 9250 & - \\
\hline IX & AlKFF $\downarrow$ TR & $0.23 \pm 0.02$ & $0.04 \pm 0.01$ & 174 & - \\
\hline$x$ & $A I K F F \downarrow I R$ & $0.27 \pm 0.07$ & $0.05 \pm 0.01$ & 185 & - \\
\hline XI & AlKFF $\downarrow \mathbf{K R}$ & Poorly hydrolysed* & & & $0.15 \pm 0.01$ \\
\hline XII & AlKFF $\downarrow \mathbf{V R}$ & Poorly hydrolysed* & & & $0.22 \pm 0.02$ \\
\hline
\end{tabular}


Table 2 Kinetic parameters and inhibition constants $\left(K_{i}\right)$ for the simple linear competitive inhibition of hK1 for the internally quenched fluorescent peptides derived from the reactive-centre loop of kallistatin, with modifications at the $\mathrm{P}_{2}{ }_{2}$ position

Conditions: $20 \mathrm{mM}$ Tris- $\mathrm{HCl}$ and $1 \mathrm{mM}$ EDTA, $\mathrm{pH} 9$, at $37^{\circ} \mathrm{C}$. *Poorly hydrolysed means that at least $70 \%$ of the initial peptide concentration $(10 \mu \mathrm{M})$ remained intact after a 4-h incubation period with $1 \mathrm{nM}$ hK1 (the usual kinetic assay enzyme concentration). The cleavage point was determined after an overnight incubation. $\uparrow K_{i}$ determined in $20 \mathrm{mM}$ Tris/ $/ \mathrm{HCl}, 1 \mathrm{mM}$ EDTA, pH 9, at $37^{\circ} \mathrm{C}$ over the hydrolysis of $20 \mu \mathrm{M}$ Pro-Phe-Phe-methyl coumarine amide $\left(K_{\mathrm{m}}=70 \mu \mathrm{M}, K_{\text {cat }}=12.5 \mathrm{~s}^{-1}[15]\right)$, employing $1 \mathrm{nM}$ hK1. Cleavage sites are indicated with an arrow $(\downarrow)$. One-letter symbols have been used to represent amino acids and letters in bold denote the mutated residues.

\begin{tabular}{|c|c|c|c|c|c|}
\hline No. & $\begin{array}{l}\text { Abz-peptidyl- } \\
\text { Glu-EDDnp }\end{array}$ & $\begin{array}{l}K_{\mathrm{m}} \\
(\mu \mathrm{M})\end{array}$ & $\begin{array}{l}k_{\text {cat }} \\
\left(s^{-1}\right)\end{array}$ & $\begin{array}{l}k_{\text {cat }} / K_{\mathrm{m}} \\
(\mathrm{mM} \cdot \mathrm{s})^{-1}\end{array}$ & $\begin{array}{c}K_{\mathrm{i}} \dagger \\
(\mu \mathrm{M})\end{array}$ \\
\hline XIII & AlKFF $\downarrow S A$ & $1.79 \pm 0.11$ & $0.54 \pm 0.01$ & 302 & - \\
\hline XIV & AIKFF $\downarrow S E$ & Poorly hydrolysed* & & & $0.51 \pm 0.02$ \\
\hline$X V$ & AIKFF $\downarrow S L$ & Poorly hydrolysed* & & & $0.19 \pm 0.01$ \\
\hline$X V I$ & AIKFF $\downarrow S N$ & Poorly hydrolysed ${ }^{*}$ & & & $0.73 \pm 0.04$ \\
\hline$X V I I$ & AIKFF $\downarrow S P$ & $1.25 \pm 0.26$ & $0.05 \pm 0.01$ & 40 & - \\
\hline$X V I I I$ & $A I K F F \downarrow S Q$ & Poorly hydrolysed* & & & $0.60 \pm 0.05$ \\
\hline$X I X$ & $A I K F F \downarrow S S$ & $0.94 \pm 0.12$ & $0.30 \pm 0.01$ & 319 & - \\
\hline$X X$ & AIKFF $\downarrow S T$ & Poorly hydrolysed* & & & $0.32 \pm 0.03$ \\
\hline VIII & AlKFF $\downarrow S R$ & $0.36 \pm 0.01$ & $3.33 \pm 0.15$ & 9250 & - \\
\hline$X X I$ & $A I K F F \downarrow S I$ & Poorly hydrolysed* & & & $1.0 \pm 0.1$ \\
\hline$X X I I$ & AIKFF $\downarrow S K$ & $0.21 \pm 0.03$ & $0.12 \pm 0.02$ & 571 & - \\
\hline$X X I I I$ & AIKFF $\downarrow S V$ & Poorly hydrolysed* & & & $1.7 \pm 0.2$ \\
\hline
\end{tabular}

the determination of the kinetic parameters. All the other peptides were recognized by $\mathrm{hK}_{1}$ and were able to effectively bind to the active site of the enzyme, as indicated by the low $K_{\mathrm{i}}$ values, and limited hydrolysis was observed only after $4 \mathrm{~h}$ of incubation with hK1. The $K_{\mathrm{i}}$ values for the modifications at $\mathrm{P}_{1}^{\prime}$ were approx. $0.30 \mu \mathrm{M}$. A proline residue at this position resulted in a peptide (V), which was completely resistant to hydrolysis but was able to inhibit $\mathrm{hK}_{1}$ with the lowest $K_{\mathrm{i}}$ value throughout the series. It is noteworthy that peptide VIII (containing a serine residue) was hydrolysed with a specificity constant $\left(k_{\text {cat }} / K_{\mathrm{m}}\right)$ that was 50 -fold higher than other susceptible peptides containing Gln, Thr and Ile (peptides VI, IX and X respectively), and this difference was due mainly to the higher catalytic constant $\left(k_{\text {cat }}\right)$ of peptide VIII hydrolysis.

\section{$\mathbf{P}_{2}$ position}

The kinetic parameters for hydrolysis of the peptides derived from the internally quenched fluorescent peptide Abz-Ala-Ile-Lys-PhePhe-Ser-Arg-Gln-EDDnp, with modifications at the $\mathrm{P}_{2}^{\prime}$ position, are presented in Table 2. Although all the peptides of this family contain Ser at $\mathrm{P}_{1}^{\prime}$, which was the best amino acid residue at this position, only the peptides with Arg, Ala, Pro, Ser and Lys (VIII, XIII, XVII, XIX and XXII respectively in Table 2) were hydrolysed with velocities that allowed the determination of the kinetic parameters. The $\mathrm{S}_{2}^{\prime}$ subsite of hK1 also seems to have a specificity as restricted as that of its $\mathrm{S}_{1}^{\prime}$ subsite for the hydrolysis of peptide substrates. The most efficiently hydrolysed peptide was the reference peptide (peptide VIII in Table 2), which contains $\operatorname{Arg}$ at the $\mathrm{P}_{2}^{\prime}$ position. All the poor substrates of this series were assayed as competitive inhibitors, and the $K_{\mathrm{i}}$ values obtained were in the range $0.2-1.7 \mu \mathrm{M}$. The lowest $K_{\mathrm{i}}$ value was obtained with the peptide $\mathrm{XV}$ that contained Leu in the $\mathrm{P}_{2}^{\prime}$ position.
Table 3 Determination of the inhibitory constant $\left(K_{\mathrm{i}}\right)$ for the simple linear competitive inhibition of human tissue kallikrein for peptides synthesized, based on the kinetic parameters obtained from Tables 1 and 2

$K_{\mathrm{i}}$ was determined using the following conditions: $20 \mathrm{mM}$ Tris/ $\mathrm{HCl}$ and $1 \mathrm{mM}$ EDTA, $\mathrm{pH}$ 9, at $37^{\circ} \mathrm{C}$ over the hydrolysis of $20 \mu \mathrm{M}$ Pro-Phe-Phe-methyl coumarine amide $\left(K_{\mathrm{m}}=70 \mu \mathrm{M}\right.$, $k_{\text {cat }}=12.5 \mathrm{~s}^{-1}[15]$ ) with $1 \mathrm{nM}$ hK1. One-letter symbols (with lowercase letters corresponding to the $\mathrm{D}$-form) have been used to denote amino acids.

\begin{tabular}{llc}
\hline No. & Peptide & $K_{\mathrm{i}}(\mu \mathrm{M})$ \\
\hline XXIV & Abz-kFFPrQ-EDDnp & $0.029 \pm 0.001$ \\
XXV & Abz-kFRPrQ-EDDnp & $0.022 \pm 0.001$ \\
XXVI & Acetyl-kFRPrQ-EDDnp & $0.424 \pm 0.020$ \\
XXVII & Acetyl-kFRPr-NH & $4.40 \pm 0.08$ \\
XXVIII & Acetyl-kFFPrQ-NH & $0.494 \pm 0.015$ \\
XXIX & Acetyl-kFFPLE-NH & $0.029 \pm 0.004$
\end{tabular}

\section{Design of inhibitors}

Table 3 presents the $K_{\mathrm{i}}$ values for the peptides synthesized, based upon the information gathered from Tables 1 and 2, and from previously reported specificity studies at non-prime sites of hK1 subsites [19]. In the peptides Abz-Lys-Phe-Phe-Pro-Arg-GlnEDDnp and Abz-Lys-Phe-Arg-Pro-Arg-Gln-EDDnp (XXIV and $\mathrm{XXV}$ in Table 3; letters in italics denote the D-form of the amino acid), Lys and Arg were introduced in their D-enantiomeric form in order to provide resistance to hydrolysis and solubility to the peptides. In addition, the $K_{\mathrm{m}}$ values for the peptides containing Lys at $\mathrm{P}_{3}$ positon [19] and Arg at $\mathrm{P}_{2}^{\prime}$ (Table 2) were in the lower range of the obtained values. The amino acid Phe was maintained in the $\mathrm{P}_{2}$ position because it is present in the best synthetic short substrates $[25,26]$. Phe or Arg were introduced at the $\mathrm{P}_{1}$ position of these inhibitors in order to compare the fitting of these amino acids at the $S_{1}$ subsite of hK1. Pro was maintained in all peptides because its presence at $\mathrm{P}_{1}^{\prime}$ resulted in resistance of peptide $\mathrm{V}$ and a low $K_{\mathrm{i}}$ value (Table 1$)$. Abz was substituted by an acetyl group (peptides XXVI to XXIX), and the effects of Gln and EDDnp were examined in peptides XXVII and XXVIII, in which they were removed.

Arg and $P$ he at $P_{1}$ in this setting of peptides have the same effect in binding to the enzyme. The substitution of Abz with an acetyl group increased the $K_{\mathrm{i}}$ value one order of magnitude (compare peptides XXV and XXVI). The C-terminal Gln-EDDnp seemed to play a significant role in the binding of these peptides, because the highest $K_{\mathrm{i}}$ value was obtained with the peptide XXVII, in which Gln-EDDnp is absent. When only EDDnp was removed (compare peptides XXVI and XXVIII), no significant variation was observed in the $K_{\mathrm{i}}$ values. Finally, the peptide XXIX was synthesized by replacing Leu and Glu-amide with D-Arg and EDDnp respectively, and resulted in a inhibitor of hK1 with $K_{\mathrm{i}}$ of $0.029 \mu \mathrm{M}$, which is similar to values obtained for the peptides XXIV and XXV (Table 3). Leu was introduced in peptide XXIX because with this amino acid at $\mathrm{P}_{2}^{\prime}$, the lowest $K_{\mathrm{i}}$ value was obtained in the series shown in Table 2, and Glu was introduced to substitute the negative environment provided by the two $\mathrm{NO}_{2}$ groups of EDDnp.

The inhibitory specificity activity of acetyl-Lys-Phe-Phe-ProLeu-Glu- $\mathrm{NH}_{2}$ for hK1 was evaluated by comparing the inhibitory effect of this peptide on human thrombin, activated factor X (FXa), plasmin, trypsin, cathepsin G and plasma kallikrein. Surprisingly, as shown in Table 4, human plasma kallikrein was inhibited by acetyl-Lys-Phe-Phe-Pro-Leu-Glu- $\mathrm{NH}_{2}$ with a $K_{\mathrm{i}}$ value which was lower than that of hK1. All other proteases were less susceptible to inhibition by this peptide. 
Table 4 Determination of the inhibition constant $\left(K_{i}\right)$ of acetyl-Lys-PhePhe-Pro-Leu-Glu- $\mathrm{NH}_{2}$ on human serine proteases compared with hK1

\begin{tabular}{lc}
\hline Enzyme & $K_{\mathrm{i}}(\mathrm{nM})$ \\
\hline Thrombin & $700 \pm 80$ \\
Factor Xa & $130 \pm 10$ \\
Plasmin & $170 \pm 11$ \\
Bovine trypsin & $\mathrm{NI}^{*}$ \\
Cathepsin G & $170 \pm 10$ \\
Human plasma kallikrein & $8 \pm 0.2$ \\
Human tissue kallikrein & $29 \pm 2$
\end{tabular}

* No inhibition until $30 \mu \mathrm{M}$ peptide concentration.

\section{DISCUSSION}

The specificities of the subsites $S_{1}{ }_{1}$ and $S_{2}{ }_{2}$ of hK1 play determinant roles in the recognition and hydrolysis of substrates. The presence of Ser and Arg at positions $\mathrm{P}_{1}^{\prime}$ and at $\mathrm{P}_{2}^{\prime}$ respectively, resulted in the best substrate (Abz-Ala-Ile-Lys-Phe-Phe-Ser-Arg-GlnEDDnp) out of those derived from the kallistatin reactive-centre loop sequence. Any other amino acid at $\mathrm{P}_{1}^{\prime}$ or $\mathrm{P}_{2}^{\prime}$ resulted in peptides that were hydrolysed very slowly, and the $k_{\text {cat }}$ constants, for those with values that could be determined, were at least one order of magnitude lower than that of the hydrolysis of Abz-Ala-Ile-Lys-Phe-Phe-Ser-Arg-Gln-EDDnp. It is noteworthy that Lys-bradykinin (kallidin) is released by $\mathrm{hK} 1$ from human kininogen, which is its natural substrate, by two cleavage events, one faster with Ser at $\mathrm{P}_{1}^{\prime}$ position for hydrolysis of $\mathrm{Arg}^{389}$ $\mathrm{Ser}^{390}$ bond, and a second with Arg at $\mathrm{P}_{2}^{\prime}$ for the hydrolysis of Met $^{379}$-Lys ${ }^{380}$ bond [11]. According to these observations, two very efficient substrates for hK1 were described previously, AbzPhe-Arg-Ser-Arg-EDDnp $\left(k_{\text {cat }}=5.7 \mathrm{~s}^{-1}, K_{\mathrm{m}}=0.15 \mu \mathrm{M}, k_{\text {cat }} / K_{\mathrm{m}}\right.$ $=38000 \mathrm{mM}^{-1} \cdot \mathrm{s}^{-1}$ ) [27]), and the short internally quenched fluorescent peptide Abz-Phe-Arg-Ser-EDDnp $\left(k_{\text {cat }}=1.3 \mathrm{~s}^{-1}\right.$, $K_{\mathrm{m}}=0.28 \mu \mathrm{M}, k_{\text {cat }} / \mathrm{K}_{\mathrm{m}}=4643 \mathrm{mM}^{-1} \cdot \mathrm{s}^{-1}$ ) [28]. In addition, somatostatin was described as being hydrolysed at the Phe-Trp bond by hK1 with Lys present at the $\mathrm{P}_{2}^{\prime}$ position; however, an efficient substrate derived from somatostatin was obtained by putting Ser and Arg at $\mathrm{P}_{1}^{\prime}$ and $\mathrm{P}_{2}^{\prime}$ positions respectively, resulting in the internally quenched fluorescent peptide Abz-Lys-Asn-PhePhe-Ser-Arg-Gln-EDDnp $\left(k_{\text {cat }}=2.5 \mathrm{~s}^{-1}, K_{\mathrm{m}}=0.29 \mu \mathrm{M}, k_{\text {cat }} / K_{\mathrm{m}}\right.$ $=8620 \mathrm{mM}^{-1} \cdot \mathrm{s}^{-1}$ ) [19]. Therefore the specificities of $\mathrm{S}_{1}^{\prime}$ and $\mathrm{S}_{2}^{\prime}$ of tissue kallikrein seems to be as determinant as that of $S_{2}$, which requires hydrophobic, and preferentially aromatic, amino acids $[19,25]$ because of the hydrophobic crevice between $\mathrm{Tyr}^{99}$ and $\operatorname{Trp}^{215}$ at the $\mathrm{S}_{2}^{\prime}$ subsite of human and porcine tissue kallikrein $[16,17]$. The $S^{\prime}{ }_{1}$ and $S^{\prime}{ }_{2}$ subsites of tissue kallikreins are not well defined, although Ala and Lys in bovine pancreatic trypsin inhibitor (PTI) occupy these subsites of porcine tissue kallikrein in the crystal structure of the complex formed by them [17]. All together, these structural and kinetic observations suggest that $S_{1}{ }_{1}$ preferentially accepts residues with short side chains and $\mathrm{S}_{2}^{\prime}$ preferentially accepts residues with basic side chains. In the described structure of PTI-tissue kallikrein complex, $\mathrm{S}_{1}{ }_{1}$ contains a histidine residue that could establish convenient hydrogen bonds with the serine side chain, and the basic residue of PTI interacts with the main chain of the enzyme and is partially exposed to solvent. In addition, the results presented in Tables 1 and 2 suggest that the occupancy of $S_{1}^{\prime}$ and $S^{\prime}{ }_{2}$ hK1 subsites determines whether a particular peptide will be preferentially a substrate or an inhibitor. As some hydrolysis was detected with most of the assayed peptides, an acyl-enzyme intermediate must be formed with each peptide, but the amino leaving fragment of those slowly hydrolysed peptides could stay in the hK1 for a longer time, allowing a back reaction. This situation would be similar to those observed for classical serine proteinase inhibitors, where the favourable conditions of the back reaction seems to be the main component for the high inhibitory activity of the classical proteinaceous inhibitors [29]. In these inhibitors, the retention of the amino fragment of the inhibitor is guaranteed by the rigidity of the inhibitor-enzyme structure provided by a network of hydrogen bonds inside the inhibitor. In the case of our small peptides, the retention of the amino fragment could be a result of its strong interaction with the prime subsites of hK1.

Using the information obtained with the peptides presented in Tables 1 and 2, six peptides were designed as inhibitors of hK1 (Table 3). Three out of the six peptides (Abz-LysPhe-Phe-Pro-Arg-Gln-EDDnp, Abz-Lys-Phe-Arg-Pro-Arg-GlnEDDnp and acetyl-Lys-Phe-Phe-Pro-Leu-Glu- $\mathrm{NH}_{2}$ ) inhibited $\mathrm{hK} 1$ in the range $20-30 \mathrm{nM}$. They were resistant to hydrolysis by hK1 and, surprisingly, hK1 accepted Pro at $\mathrm{S}_{1}{ }_{1}$ and D-amino acids at $S_{3}$ and $S_{2}^{\prime}$ subsites. It is noteworthy that the inhibitory activity of the peptide acetyl-Lys-Phe-Phe-Pro-Leu-Glu- $\mathrm{NH}_{2}$ was due mainly to the presence of Glu at the $S_{3}^{\prime}$ position. This result suggests that the negative side chain of Glu could be playing the same role of the EDDnp, in which $\mathrm{NO}_{2}$ groups introduce a strong polarization on this group and expose a negative group that could interact favourably with hK1. The peptide acetyl-Lys-Phe-Phe-Pro-Leu-Glu- $\mathrm{NH}_{2}$ inhibited other serine proteases with higher $K_{\mathrm{i}}$ values, apart from human plasma kallikrein which has a $K_{\mathrm{i}}$ value of $8 \mathrm{nM}$. This is a surprising result, since this enzyme is known to be a restricted arginylhydrolase, and a specific inhibitor of human plasma kallkrein [30], PKSI-527 (trans-4-aminomethylcyclohexenecarbonyl-Lphenylalanine-4-carboxymethylanilide), was described, which is supposed to interact with the negatively charged $S_{1}$ subsite of human plasma kallikrein with the trans-4-aminomethylcyclohexenecarbonyl moiety of the molecule. Although acetylLys-Phe-Phe-Pro-Leu-Glu- $\mathrm{NH}_{2}$ has the basic side chain of $\mathrm{D}$-lysine, it is not reasonable to propose that the lysine side chain interacts with the $S_{1}$ subsite of plasma kallikrein.

In conclusion, we report a restricted specificity of subsites $S_{1}^{\prime}$ and $S^{\prime}{ }_{2}$ of $h K 1$ and we also found a particular peptide sequence that could be a leader compound to design specific inhibitor for hK1 or for plasma kallikrein or for both at same time. The development of compounds that inhibit both kallikreins could be of even more interest if the inhibition of kinin release is the main goal.

This work was supported by Fundação de Amparo Pesquisa do Estado de São Paulo (FAPESP), Conselho Nacional de Desenvolvimento Científico e Tecnológico (CNPq) and Human Frontiers for Science Progress (RG 00043/2000-M).

\section{REFERENCES}

1 Bhoola, K. D., Figueroa, C. D. and Worthy, K. (1992) Bioregulation of kinins: kallikreins, kininogens, and kininases. Pharmacol. Rev. 44, 1-80

2 MacDonald, R. J., Margolius, H. S. and Erdös, E. G. (1988) Molecular biology of tissue kallikrein. Biochem. J. 253, 313-321

3 Yousef, G. M. and Diamandis, E. P. (2001) Expanded human tissue kallikrein family - a novel panel of cancer biomarkers. Tumour Biol. 23, 185-192

4 Christiansen, S. C., Proud, D. and Cochrane, C. G. (1987) Detection of tissue kallikrein in the bronchoalveolar lavage fluid of asthmatic subjects. J. Clin. Invest. 79, 188-197

5 Proud, D., Togias, A., Naclerio, R. M., Crush, S. A., Norman, P. S. and Lichtenstein, L. M. (1983) Kinins are generated in vivo following nasal airway challenge of allergic individuals with allergen. J. Clin. Invest. 72, 1678-1685 
6 Braumgarten, C. R., Nichols, R. C., Naclerio, R. M. and Proud, D. (1986) Concentrations of glandular kallikrein in human nasal secretions increase during experimentally induced allergic rhinitis. J. Immunol. 137, 1323-1328

7 Axen, R., Gross, E., Witkop, B., Pierce, J. V. and Webster M. E. (1966) Release of kinin activity from human kininogens and fresh plasma by cyanogen bromide. Biochem. Biophys. Res. Commun. 5, 353-357

8 Alhenc-Gelas, F., Marchetti, J., Alegrini, J., Carod, P. and Menard, J. (1981) Measurement of urinary kallikrein activity. Species differences in kinin production. Biochim. Biophys. Acta 677, 477-488

9 Kato, H., Enjyoji, K., Miyata, T., Hayashi, I., Oh-ishi, S. and Iwagaga, S. (1985) Demonstration of arginyl-bradykinin moiety in rat HMW kininogen: direct evidence for liberation of bradykinin by rat glandular kallikreins. Biochem. Biophys. Res. Commun. 127, 289-295

10 Hosoi, K., Tsunasawa, S., Kurihara, K., Aoyama, H., Ueha, T., Murai, T. and Sukiyama, F. (1994) Identification of mK1, a true tissue (glandular) kallikrein of mouse submandibular gland: tissue distribution and a comparison of kinin-releasing activity with other submandibular kallikreins. J. Biochem. (Tokyo) 115, 137-143

11 Del Nery, E., Chagas, J. R., Juliano, M. A., Prado, E. S. and Juliano, L. (1995) Evaluation of the extent of the binding site in human tissue kallikrein by synthetic substrates with sequences of human kininogen fragments. Biochem. J. 312, 233-238

12 Chagas, J. R., Portaro, F. C. V., Hirata, I. Y., Almeida, P. C., Juliano, M. A., Juliano, L. and Prado, E. S. (1995) Determinants of the unusual cleavage specificity of lysyl-bradykinin-releasing kallikreins. Biochem. J. 306, 63-69

13 Zhou, G. X., Chao, L. and Chao, J. (1992) Kallistatin: a novel human tissue kallikrein inhibitor. Purification, characterization, and reactive center sequence J. Biol. Chem. 267 25873-25880

14 Chai, K. X., Chen, L.-M., Chao, J. and Chao, L. (1993) Kallistatin: a novel human serine proteinase inhibitor. Molecular cloning, tissue distribution and expression in Escherichia coli. J. Biol. Chem. 268, 24498-24505

15 Pimenta, D. C., Juliano, M. A. and Juliano, L. (1997) Hydrolysis of somatostatin by human tissue kallikrein after the amino acid pair Phe-Phe. Biochem. J. 327, 27-30

16 Katz, B. A., Liu, B. S., Bames, M. and Springman, E. B. (1998) Crystal structure of recombinant human tissue kallikrein at $2.0 \AA$ A resolution. Protein Sci. 7, 875-885

17 Chen, Z. and Bode, W. (1983) Refined 2.5 ̊ X-ray crystal structure of the complex formed by porcine kallikrein $A$ and the bovine pancreatic trypsin inhibitor. Crystallization, Patterson search, structure determination, refinement, structure and comparison with its components and with the bovine trypsin-pancreatic trypsin inhibitor complex. J. Mol. Biol. 164, 283-311

Received 17 December 2002/6 February 2003; accepted 11 February 2003 Published as BJ Immediate Publication 11 February 2003, D0I 10.1042/ BJ20021952
18 Schechter, I. and Berger, A. (1967) On the size of the active site in proteases. I. Papain. Biochem. Biophys. Res. Comm. 27, 157-162

19 Pimenta, D. C., Chao, J., Chão, L., Juliano, M. A. and Juliano, L. (1999). Specificity of human tissue kallikrein towards substrates containing Phe-Phe pair of amino acids. Biochem. J. 339, 473-479

20 Hirata, I. Y., Cezari, M. H. S., Nakaie, C., Boschcov, P., Ito, A. S., Juliano, M. and Juliano, L. (1994) Internally quenched fluorogenic protease substrates: solid-phase synthesis and fluorescence spectroscopy of peptides containing ortho-aminobenzoyl/ dinitrophenyl groups as donor-acceptor pairs. Lett. Peptide Sci. 1, 299-308

21 Shimamoto, K., Chao, J. and Margolius, H. S. (1980) The radioimmunoassay of human urinary kallikrein and comparisons with kallikrein activity measurements. J. Endocrinol. Metab. 51, 840-848

22 Sampaio, C. A. M., Sampaio, M. U. and Prado, E. S. (1984) Active-site titration of horse urinary kallikrein. Hoppe-Seyler's Z. Physiol. Chem. 365 , 297-302

23 Wilkinson, G. N. (1961) Statistical estimations in enzyme kinetics. Biochem. J. 80, 324-332

24 Nicklin, M. J. and Barrett, A. J. (1984) Inhibition of cysteine proteinases and dipeptidyl peptidase I by egg-white cystatin. Biochem. J. 223, 245-253

25 Oliveira, L., Araujo-Viel, M. S., Juliano, L. and Prado, E. S. (1987) Substrate activation of porcine pancreatic kallikrein by $\mathrm{N}-\alpha$-derivatives of arginine 4-nitroanilides. Biochemistry 26, 5032-5035

26 Fiedler, F., Geiger, R., Hirschauer, C. and Leysath, G. (1978). Peptide esters and nitroanilides as substrates for the assay of human urinary kallikrein. Hoppe-Seylers Z. Physiol. Chem. 359, 1667-1673

27 Chagas, J. R., Juliano, L. and Prado, E. S. (1991) Intramolecularly quenched fluorogenic tetrapeptide substrates for tissue and plasma kallikreins. Anal. Biochem. 192, 419-425

28 Melo, R. L., Alves, L. C., Del Nery, E., Juliano, L. and Juliano, M. A. (2001) Synthesis and hydrolysis by cysteine and serine proteases of short internally quenched fluorogenic peptides. Anal. Biochem. 293, 71-77

29 Radisky, E. S. and Koshland Jr, D. E. (2002) A clogged gutter mechanism for protease inhibitors. Proc. Natl. Acad. Sci. U.S.A. 99, 10316-10321

30 Wanaka, K., Okada, Y., Tsuda, Y., Okamoto, U., Hijikata-Okunomiya, A. and Okamoto, S. (1992) Synthesis of trans-4-aminomethylcyclohexanecarbonyl-L- and -D-phenylalanine-4-carboxymethylanilide and examination of their inhibitory activity against plasma kallikrein. Chem. Pharm. Bull. 40, 1814-1817 